\title{
An Overview of the Key Theories of Foreign Direct Investment: The Way Forward
}

\author{
Edward E. Marandu \\ University of Botswana, \\ Faculty of Business, Marketing Department \\ P.O. Box 70243, Gaborone, Botswana \\ Tebo Ditshweu \\ University of Botswana, \\ Faculty of Business, Marketing Department \\ Private Bag 00703, Gaborone, Botswana
}

\begin{abstract}
This paper discusses eight of the numerous theories that seek to explain why and when foreign direct investment takes place. In addition, general criteria for a good theory were provided as suggested. The main finding is that there is no single, generally accepted theory that currently satisfies all the listed criteria for a good theory or gives a satisfactory explanation about the determinants of FDI. The paper argues that a good theory of FDI should be able to explain simultaneously exporting as well as portfolio and foreign direct investments for these are basically similar activities that reflect a continuum of increasing level of involvement of the firm in international operations. The authors advise that a good starting point in developing a theory of FDI the theory of economic advantage which is static and more applicable to natural advantages such as minerals and agriculture. On the other hand, the Product Life Cycle Theory is dynamic and suggests that comparative advantage shifts from one nation to another as a product matures. Therefore, the PLC may be a good starting point in developing a theory of FDI flows associated with products that depend mainly on acquired advantages such as manufactured goods. The PLC may therefore be seen as taking over where the classical comparative advantage theory fails to explain trade and investment.
\end{abstract}

\section{INTRODUCTION}

Foreign Direct Investment (FDI) is a confused area of study! Several theories have been put forward to explain why and when FDI takes place. However, no single, unified, generally accepted theory that explains the different types of FDI exists. Attempts at building theories explaining FDI behavior rely heavily on borrowing from the various disciplines such as economics, industrial organization and behavioral sciences in an eclectic or fragmentary basis. The result has been that knowledge on FDI exists in fragments which do not come together into a coherent pattern of received wisdom. It is in this context that an attempt is made in this paper to examine various theories that explain FDI. The paper presents the main theories of FDI, exposes their limitations and identifies common threads among some of them. This may help provide the basis for a comprehensive theory of FDI.

What is FDI? What is a theory? These are questions to which there should be clear answers if a theory is to be developed to explain why and when FDI occurs.

\section{The Concept of Foreign Direct Investment}

Foreign Direct Investment (FDI) is an investment made directly by a firm based in one country, into a firm based in another country (Investopedia, 2018). Foreign direct investments differ 
substantially from indirect investments such as portfolio flows, wherein overseas institutions invest in equities listed on a nation's stock exchange.

FDI is direct because the investor acquires "a lasting interest" and "an effective voice" in the management or control of the foreign company (International Monetary Fund, 1993). FDI generally takes one of the following equity forms: green-field investment, acquisition, joint ventures, and reinvested company earnings (Stewart, 1994). In addition to equity participation, FDI also includes other non-equity forms of investment such as franchising, licensing and turnkey agreements (Nayyar, 2014). Firms entering a host country through FDI have a long-term perspective.

FDI is in contrast to Foreign Portfolio Investment (FPI) which is indirect in the sense that the investors are not interested in involvement in the management or control of a company. Portfolio investment includes investment in a number of securities such as foreign stocks, government bonds only to earn financial returns without any intent to own, control or manage the domestic firms (Ichiro, 1991). Thus while FDI is active, FPI is passive.

\section{Nature of Theories}

According to several authors (Mittelstaedt, 1977; Zaltman \& Wallendorf, 1979; Wacker, 1998) a theory is a statement of relationship among factors observed in the empirical world. This provides a systematic way of understanding events, behaviors or situations. A theory can therefore be used to explain or predict events. Authors usually agree that the salient features of a good theory include the characteristics in Table 1 which are explanatory power, predictive power, factual basis, general, unifying power, face validity and simplicity.

\section{Characteristic}

1. Explanatory power

2. Predictive power

3. Factual basis

4. General

\section{Unifying power}

6. Face validity

7. Validity

8. Simplicity Adapted from Mittelstaedt (1977), Zaltman \& Wallendorf (1979) and Wacker (1998)

\section{Explanation}

A good theory should possess the ability to tell why and how a specific relationships leads to specific events.

A good theory should have the capability to forecast what will occur at some future time provided certain conditions are met.

A good theory should be supported by facts.

A good theory should be broad so as to cover a wide range of relevant situations. Thus a good theory of FDI should be sufficiently broad so as to cover a wide range of FDI situations.

A good theory should have the capability to bring together areas which have previously been viewed as unrelated.

A good theory should, be plausible; that is on the surface, seem to make sense.

A good theory must be verifiable, in the sense that it should be possible to test the relationships hypothesized by the theory.

Finally, a good theory should be simple enough that it can be understood.

\section{Table 1: Characteristics of a Good Theory}

\section{KEY THEORIES OF FDI}

\section{Rate of Return Theory}

One of the earliest theories explaining FDI is the neo classical theory of Rate of Return on Investment. The theory postulates that the most important reason for investing directly overseas is differences in the rate of return on investment between different nations. The theory posits that, all things being equal, capital tends to flow from low returns to high returns countries in order to gain the best returns. This arbitrage phenomenon will persist until all countries have the same return on capital. However, this theory fails to explain the difference between portfolio investment and FDI. FDI involves control but portfolio investment is not necessarily about control. If interest rates are higher overseas, an investor would consider 
lending money overseas, but there is no imperative for that investor to control the firm to which the money has been lent (Hymer, 1976). Thus, the main shortcoming of the rate of return theory is failure to explain the element of control. In fact, prior to 1950, FDI was viewed as a special case of portfolio investment (Dinkar \& Rahul, 2014). At that time there was no separate theory for FDI.

\section{Monopolistic Advantage Theory}

Hymer is one of the pioneers who established a systematic approach towards the study of FDI. His contributions are found in his seminal doctoral dissertation, presented in 1960, but published posthumously in 1976 by Charles P. Kindleberger, his dissertation supervisor. His FDI theory of industrial organization was one of the first works to explain international production. The core of Hymer's theory is that firms operating in foreign countries have to compete with domestic firms that are in an advantageous situation in terms of consumer preference, language, culture, legal systems and no foreign exchange risk.

These disadvantageous must be offset by some form of market power in order to make FDI profitable. According to Lall (1976) market power can be acquired only under conditions of imperfect competition. The sources of market power, called "firm-specific advantages" in Hymer's terminology or "monopolistic advantage" in Kindleberger's terminology, are in the form of possession of superior technology, patent-protected products, brand names, management skills, economies of scale and cheaper sources of finance. In other words, TransNational Corporations develop competitive advantage from home country based market imperfections resulting from monopolistic or oligopolistic market situations.

The main contribution of Hymer was transformation of FDI theory from neoclassical trade theories into the industrial organization discipline. However, Hymer's thesis suffers from several weaknesses.

1. First, possessing firm-specific advantages does not automatically mean FDI as firms might very well exploit their advantages through exporting or licensing (Robock \& Simmonds, 1983).

2. Second, a number of other factors influence the choice between FDI and licensing/exports, including host government policy, size of host market, the reaction of competitors and the political risk of investment (Dinkar \& Rahul, 2014).

3. Third, Hymer's theory is static for it does not explain changes in patterns of FDI flows with time. Before World War Two the destination of the bulk of investment went to less developed countries (letto-Gilles, 1992). This is consistent with Hymer's theory. However, after World War Two, contrary to expectations, the bulk of FDI has been attracted to other developed countries rather than to less developed countries (Table 2). According to letto-Gilles the motivation for FDI in prewar years was vertical integration in order to secure supplies of natural resource. After the War, improvements in technological innovations led to large scale manufacturing that led to more FDI being directed towards other developed countries of the larger potential market there.

Table 2: Percentage FDI Stock in Selected Years 1914 - 1985

\begin{tabular}{|c|c|c|c|c|c|c|c|c|c|}
\hline Host & 1914 & 1938 & 1960 & 1971 & 1975 & 1978 & 1980 & 1983 & 1985 \\
\hline Developed & 37.2 & 34.3 & 67.3 & 65.2 & 75.1 & 69.6 & 71.1 & 75.6 & 75.0 \\
\hline LDC & 62.8 & 65.7 & 32.3 & 30.9 & 24.9 & 27.8 & 26.6 & 24.4 & 25.0 \\
\hline Unallocated & 0 & 0 & 0.4 & 3.9 & 0 & 2.6 & 2.3 & 0 & 0 \\
\hline
\end{tabular}


In summary, Hymer's thesis offers incomplete explanation for FDI because it fails to explain why, where and when FDI takes place. This has been carried out by the Location Theory (Krugman, 1991), Internalization Theory (Buckley \& Casson, 1976), the Product Life Cycle (PLC) Theory (Vernon, 1966; Wells, 1968) and the Eclectic Theory (Dunning, 1977).

\section{Location Theory}

Location theory posits that multinational corporations choose a location which is close to markets or raw materials. It emphasises that every host country location is characterized by a set of factors that may attract or repel investment. The factors can be classified into two broad groups. First, there are locational endowments, which mainly consist of proximity to natural resources or proximity to markets. Second, there exists a range of man-made factors such as skilled labor, political, economic and infrastructural factors of a host country (Erdal \& Tatoglu, 2002). Both types of factors play an important role in a firm's decision to enter a host country through FDI.

Once a location attracts investment it begins to experience agglomeration economies - a concept advanced by Alfred Marshall in the 1890s, endures almost 130 years later as a central explanation of urban development, productivity and investment (Marshall, 1898). That is foreign investors may be attracted to areas with existing concentrations of foreign-owned firms (Guimaraes \& Figueiredo, 2000). This is natural - being less knowledgeable about the country, investors may emulate decisions of other foreign firms to reduce risk. In addition there are spillovers from the local foreign agglomeration to the pool of potential international investors (Mariotti \& Piscitello, 1995) in the form of specialized labor markets and supplier networks as well as knowledge spillovers. Further, investment in a location with substantial clustering of industries is likely to incur lower costs than in areas with dispersed industrial activities. This is because clustering saves transportation (Krugman, 1991). Thus pioneering firms tend to locate in areas that have potential to aggregate industries.

\section{Oligopolistic Theory of FDI}

According to Dinkar \& Rahul (2014), firms often exhibit imitative behavior, i.e. they follow the internationalization of competitors so that they will not lose their strategic advantage. Knickerbocker (1973) argued that in oligopolistic market conditions, firms in an industry tend to follow each other's location decision.

However, Knickerbocker's proposition of oligopolistic reaction holds time only when uncertainty exists about costs in the host country. The weakness of this theory is that it does not explain what motivated the first firm to undertake FDI.

\section{The Internalization Theory of FDI}

This theory was developed by Buckley \& Casson (1976) who postulated that transnational companies organize their internal activities so as to develop specific advantages, which can then be exploited. The theory is known as internalization because the authors stressed this point with regard to the creation of Multinational Corporations. They articulated their theory based on three simple propositions:

1. Firms maximize profits in a market that is imperfect;

2. When markets of intermediate products are imperfect, there is an incentive to bypass them by creating internal markets.

3. Internalization of markets across the world leads to MNCs.

The theory explain what happens when the external market which is available to a MNC fails to offer an efficient environment in which the business can profit by using its technology, 
production processes, know-how and brand name. Under such a situation, the firm is likely to create an internal market via investment in multiple countries and thus create the needed market to achieve its objectives. Firm creates hierarchies when either there is no market for intermediate products needed by MNC or because external market for such products is inefficient. The transaction cost of intra firm transaction is negligible compared to their market cost.

\section{The Product Life Cycle Theory of Trade}

Product Life-Cycle (Vernon, 1966) is a dynamic theory that explains changes in the trade position of a nation in the long run. It predicts that an innovative product from an advanced country, once exported, could ultimately end up being imported as the technology is transferred to the lower cost nations. The argument is that comparative advantage shifts from one nation to another as a product matures through its life cycle.

Briefly the theory assumes that, in general, trade in manufactured goods typically follows a cycle with four main phases: introduction, growth, maturity and decline. During the early stages of the cycle a product is first produced in the country which has discovered it. The new product is mainly for use in the local market and some limited for exports. At this very early stage, the innovating firm is interested in the domestic market of the product. In this early stage of the cycle, comparative advantage rests with the innovating country because of "technological gap" between the innovating country vis-a'-vis the others place the innovating country in a monopoly position. In the initial phase of the cycle, usually, manufacturing occurs in a developed country, such as the US, where the innovator is motivated by a potentially profitable market (Gichamo Tesfanesh Zekiwos, 2012).

In phase two, growth of demand in the importing nations may provide sufficient volume to justify local manufacture by the innovating firm and competitors who may copy the innovation. As production begins abroad, the exports of the initiating nation rapidly reduce because other producing countries take a share of the market. In the second phase of the cycle, usually manufacturing occurs in other advanced countries, say in Europe.

The third stage occurs as the product matures. A mature product uses an already established technology and a lower skilled labor content. In this situation, the less developed countries may be able to underprice the more advanced countries by applying their cheap less-skilled labor to the technology already designed to product. Thus the less developed nations may become attractive production points for multinational firms and begin exporting the product to more advanced countries.

The decline stage is characterized by concentration of production in emerging economies. The innovating country becomes a net importer of the product it innovated in the first place. Comparative advantage shifts from one nation to another as a product matures; and so does FDI.

However, this alone is not the only factor that influences foreign investors to invest in less developed countries as factors such as government regulations to protect their domestic enterprises from foreign competition increase. This, usually seen as a threat to MNEs, drove them to start investing directly into these markets instead, to avoid facing tariff barriers.

\section{The Eclectic FDI Theory}

The eclectic theory Dunning (1977), popularly known as OLI, is an integration of three theories. The theory posits that firms undertake FDI when the advantages of Ownership, 
Location and Internalization combine to make it appealing to undertake FDI. Ownership advantage is the benefit that a company gets due to its ownership of some special asset, such as a powerful brand, intellectual property, technical knowledge or management ability. Location advantage is the benefit of setting an economic activity in a place because of the natural or acquired characteristics of the locale. Internalization advantage is the gain that arises from undertaking a business activity in-house rather than leaving it to a relatively inefficient market. According to (Nayyar, 2014), the theory therefore holds that FDI is the result of firms possessing 0wnership specific (income generating) advantages (0) that they want to exploit in foreign Locations (L), which they cannot profitably do except through Internalization (I).

This theory further introduces the concept of a 'seeker" (Dunning \& Lundan, 2008) in which a company or an individual, is described as a 'seeker' looking into investing and is normally driven by four motives. First, there are the "natural resource seekers", who are looking for abundant natural resources at a lower cost than that of their home country. Second, there are "market seekers" who are interested in gaining access to larger markets. Third, there are "efficiency seekers", who are looking for investment in different countries so as to gain economies of scale. Finally, there are "strategic asset seekers" who want assets that will help them strengthen their competitiveness in the global marketplace.

\section{FDI Theory based on strength of currency}

Aliber (1970) and Dinkar \& Rahul (2014) made an attempt to explain FDI on the basis of the strength of currency. They posited that weaker currencies compared with stronger investing country currencies had a higher capacity to attract FDI in order to take advantage in differences in the market capitalization rate.

Aliber had tested had tested his hypothesis and found the results to be true in relation to developed countries such as the United States of America, United Kingdom and Canada.

This theory seems to be failing in explaining FDI between two or more developed countries that have currency values that are equal also it does not seem to be relevant to FDI in less developed and developing countries.

\section{SUMMING UP}

There is no single theory that explains international investment or FDI. Despite the different theories there is unanimity in that firms invest abroad to reap benefits and advantages that come with the location, currency strength, rate of return and government policies on foreign companies.

\section{SUMMARY, CONCLUSIONS AND IMPLICATIONS}

This final section ties together the entire paper. First, a summary of the theories reviewed is presented. Second, the key findings are translated into a meaningful set of conclusions. Third, based on these conclusions, the implications for FDI theory development are suggested.

\section{Summary}

This paper discussed eight of the myriad of theories that seek to explain why and when FDI takes place. Most of them try to explain why firms go to the trouble of establishing operations abroad. Such theories include Hymer's Industrial Organization Theory, Vernon's Life Cycle, The Internalization Theory of Buckley and Casson and Dunning's Eclectic Paradigm, to name a few. Other theories discussed here are location theory, oligopolistic theory and strength of currency theory. In addition, general criteria for a good theory were provided as suggested by Mittelstaedt (1977), Zaltman \& Wallendorf (1979) and Wacker (1998). 


\section{Conclusions}

1. It is worthwhile pointing out at this juncture that there is no theory of FDI which currently satisfies all the listed criteria for a good theory. To be more specific these theories have several limitations in common and individually.

2. Although several theories have tried to explain the phenomenon of FDI, there is no single, generally accepted theory that gives a satisfactory explanation about the determinants of FDI. Every new theory introduces some new elements and criticism to the previous ones. Even the most comprehensive eclectic theory does not offer an explanation good enough to be considered a general theory of FDI. Moreover, it is difficult to verify the theory empirically in its current form (Agarwal, Gubitz, \& Nunnenkamp, 1991).

3. Most of the theories focus on explaining, with limited success, on motivations for FDI from developed country perspective. These studies largely examine either why FDI flows from a developed country to a less developed country, or newly industrializing economy or another developed country. Most theories used so far essentially put forward that for FDI to occur, investing firms need to have certain unique advantages or resources, so as to be able to overcome disadvantages of operating in a foreign location and be able to compete with host country firms (Hymer, 1976). However, the driving force behind FDI by firms from less developed countries is not well understood (Kumar, 1981). For example, the rise MNCs from emerging countries like China, India, Brazil, Taiwan, South Korea and Turkey have challenged existing theory which fails to explain how do such firms that start small, lack key resources challenge established positions in the global economy and dislodge existing MNCs.

4. It appears that the difficulties in developing a general theory of FDI originate from the fact that the determinants of FDI are likely to differ among the major sectors in which foreign investors are involved. Perhaps a good starting point in identifying broad sectors for differentiated theories is Ricardo's theory of comparative advantage. According to the theory comparative advantage arises because of differing productivity of factors of production used in each country and productivity is based on natural and acquired advantages. Natural advantages include factors relating to climate, soil and mineral wealth. These cannot be created. Acquired advantages include skills, technology and marketing know-how. These can be created. Although initially developed to explain trade patterns, the theory could be used to explain the flow of FDI in to these two separate and broad sectors as behavior of investor in regard to opportunities relating to natural advantages and man-made advantages may be different. The ultimate goal however should be to develop a unified theory explaining FDI driven by both natural and acquired factors.

5. The theory of comparative advantage is static. It does not take into account changes that are taking place in the economies such as increased productivity through the learning curve and over the life cycle of products. That is economic advantage may change with time. The theory is therefore more applicable to natural advantages and may therefore form a good starting point in developing an FDI theory relating to attraction caused by natural advantages.

6. On the other hand, the Product Life Cycle Theory is a long run and dynamic theory. It emphasizes changes in the comparative advantage position of a nation in regard to trade and FDI investment over a number of years. It suggests that a newly produced good, once exported, could ultimately end up being imported as the technology and production is transferred to lower cost nations. The argument is that comparative advantage shifts from one nation to another as a product matures. While the theory of economic advantage, by implication, considers natural advantage as the main factor in determining comparative advantage; the PLC, by implication, considers acquired 
advantage, especially technology an important factor determining comparative advantage. Therefore, the PLC may be a good starting point in developing a theory of FDI flows associated with products that depend mainly on acquired advantages such as manufactured goods. The PLC may therefore be seen as taking over where the classical comparative advantage theory fails to explain trade and investment.

\section{Implications for FDI Theory Development}

There are other theories of FDI in addition to those described in this study. Few are as well constructed and most can hardly be classified as theories at all. All, at this point, have limited value for FDI policy decision and for the most part, are ignored by business practitioners. Faced with multiplicity of theories, those interested in foreign investment need some criteria specific to FDI for evaluating them. It is hereby suggested that the following criteria should be met by a coherent theory of FDI. In addition to the general criteria for a good theory suggested by Mittelstaedt (1977), Zaltman \& Wallendorf (1979) and Wacker (1998) the following FDI specific criteria should be met:

1. A good theory of FDI should be able to explain simultaneously exporting as well as portfolio and foreign direct investments. The most important characteristic of exporting, portfolio investment and FDI is the increasing level of involvement of the firm in international operations. Involvement is minimal when exporting, when a firm can merely make the products available for others to export to total involvement where the firm might operate a foreign subsidiary or production facilities. The level of involvement has significant implications in terms of levels of risk and control. Associated with higher levels of involvement is greater control and higher risk due to higher cost of investment. This suggests that there is a possibility for a common theory explaining both export trade and foreign investment. This line of thinking is not entirely new. It builds on the concept of learning process and stage by stage involvement in international business (Johanson \& Vahlne, 1977; Cavusgil, 1982). Its implication in FDI theory development is that a good theory of FDI must be able to explain why and when a firm would undertake exporting, portfolio investment or foreign direct investment.

2. Existing theories focus on explaining FDI flows from advanced to developing countries or among the developed countries. A good theory should be able to extend our current understanding FDI by explaining flows from developing countries as well. One possibility, using the eclectic theory of Dunning, is to introduce the role of government policies that encourage the upgrading of Locational advantages of the home country which in turn help create Ownership advantages of the home firms; and which they cannot profitably do except through Internalization (I). Using Ricardo's theory all these advantages can be viewed as creating comparative advantage. The PLC also fits in for it is dynamic and assumes that comparative advantage changes over the life cycle of products or projects.

3. A good theory of FDI must be able to integrate most known theories or regularities. There are many theories involved in explaining FDI behavior. In this paper we discussed eight theories. There are many more. Certainly, an adequate theory of FDI behavior must be able to accommodate these diverse theories in an integrated whole.

4. A good theory should recognize that FDI is basically determined by both uncontrollable and controllable factors. Comparative advantage theory is based on uncontrollable natural advantages. In deed one author wrote that most analysts from the African perspective assume that when it comes to Foreign Direct Investment, what comes to mind is investment in natural resources, mainly in minerals and oil (Ndiaye \& Xu, 2016). This line of thinking assumes that FDI is basically determined by uncontrollable factors and that countries with limited natural resources, will attract very little or no FDI regardless of the policies that the country pursues. On the other hand the PLC is by implication based on the underlying assumption that countries with limited natural 
resources can overcome this limitation by creating comparative advantage by taking advantage of dynamics created by product life cycle or by clearly identifying what needs to be done at the national, regional and international level in order to enhance FDI flows.

5. A good theory of FDI must be dynamic by suggesting new regularities that may be observed in the future. It is not adequate for a theory to deal with known FDI behaviors only. It must also be able to predict and anticipate other forms of FDI behaviour that extend beyond existing observations. This means that an FDI theory must have a certain level of generalization which will permit the discovery of new behaviours that may not be apparent from the accumulated actualities.

6. A good theory of FDI should provide operational definitions of the terms or constructs used to describe the theory so that the hypotheses suggested can be tested. This characteristic permits one to derive the ultimate value of a theory which is its usefulness. A good theory of FDI should be useful in terms of describing; explaining or predicting FDI behavior; if not there is little value in keeping it. We can ascertain the usefulness of a theory by developing hypotheses and subjecting them to empirical tests. To do this, the theory must be amenable to operational definitions for translating theoretical concepts into hypotheses and subjecting them to empirical tests. The lack of operational definitions in most of the existing theories of FDI constitutes their greatest weaknesses.

7. A single unified theory is preferred to eclectic borrowing from other theories. To be internally consistent, an ultimate FDI theory should be based on a single point of reference.

8. In sum this paper critically reviewed the key theories of foreign direct investment (FDI) and put forward criteria for developing a good general theory of FDI. None of the existing theories FDI meet the criteria suggested by Mittelstaedt (1977), Zaltman \& Wallendorf (1979) and Wacker (1998) and this paper. Until there is a theoretical breakthrough it is doubtful that a truly useful theory of FDI will emerge. Consequently, the practitioner of international business is advised to understand well the FDI theories that exist and put up with what they offer.

\section{References}

Agarwal, G. P., Gubitz, A., \& Nunnenkamp, P. (1991). Foreign direct Investment in Developing Countries: The case of Germany. Tbingen, Germany: J.C.B. Mohr.

Aliber, R. Z. (1970). A Theory of Direct Foreign Investment. In C. P. Kindleberger, The International Corporation, Assymposium. Combrite MA: MIT Press.

Buckley, P. J., \& Casson, M. (1976). The Future of the Multinational Enterprises. London: Macmillan.

Dinkar, N., \& Rahul, C. N. (2014). A selective review of foreign direct investment theories. Asia-Pacific Research and Training Network on Trade, 2-26.

Dunning, J. F. (1977). Trade location of economic activity and the MNE: A search of an eclectic approach. (B. Ohlin, P. O. Hesselborn, \& P. J. Wijkman, Eds.) The International Allocation of Economic Activity.

Dunning, J. H., \& Lundan, S. M. (2008). Multinational Enterprises and The Global Economy. Cheltenham: Edward Elgar Publishing.

Erdal, F., \& Tatoglu, E. (2002). Locational Determinants of Foreign Direct Investment in an Emerging Market Economy: Evidence from Turkey. Multinational Business Review, 10(1).

Gichamo Tesfanesh Zekiwos. (2012). Determinants of Foreign Direct Investment Inflows to Sub-Saharan Africa: a panel data analysis. Masters Thesis in Economics, Sordetorns University, 1-42.

Guimaraes, P., \& Figueiredo, O. (2000). Agglomeration and the Location of Foreign Direct Investment in Portugal. Journal of Urban Economics, $47,115-135$.

Agarwal, G. P., Gubitz, A., \& Nunnenkamp, P. (1991). Foreign direct Investment in Developing Countries: The case of Germany. Tbingen, Germany: J.C.B. Mohr. 
Aliber, R. Z. (1970). A Theory of Direct Foreign Investment. In C. P. Kindleberger, The International Corporation, Assymposium. Combrite MA: MIT Press.

Buckley, P. J., \& Casson, M. (1976). The Future of the Multinational Enterprises. London: Macmillan.

Dinkar, N., \& Rahul, C. N. (2014). A selective review of foreign direct investment theories. Asia-Pacific Research and Training Network on Trade, 2-26.

Dunning, J. F. (1977). Trade location of economic activity and the MNE: A search of an eclectic approach. (B. Ohlin, P. O. Hesselborn, \& P. J. Wijkman, Eds.) The International Allocation of Economic Activity.

Dunning, J. H., \& Lundan, S. M. (2008). Multinational Enterprises and The Global Economy. Cheltenham: Edward Elgar Publishing.

Erdal, F., \& Tatoglu, E. (2002). Locational Determinants of Foreign Direct Investment in an Emerging Market Economy: Evidence from Turkey. Multinational Business Review, 10(1).

Gichamo Tesfanesh Zekiwos. (2012). Determinants of Foreign Direct Investment Inflows to Sub-Saharan Africa: a panel data analysis. Masters Thesis in Economics, Sordetorns University, 1-42.

Guimaraes, P., \& Figueiredo, O. (2000). Agglomeration and the Location of Foreign Direct Investment in Portugal. Journal of Urban Economics, $47,115-135$.

Hymer, S. H. (1976). The International Operations of National Firms: A Study of Direct Foreign Investment. PhD Dissertation. Published posthumously. Cambridge, Mass, Mass: The MIT Press, 1976.

Ichiro, A. (1991). Overview: Japan's direct investment in the EC. (M. Yoshitomi, I. Akimune, T. Kitamura, G. Kume, K. Matsumoto, \& K. Totsuka, Eds.) Japanese Direct Invesment in Europe.

International Monetary Fund. (1993). Balance of Payments Manual (Fifth Edition (BPM5 ed.). Washington, D.C.

Investopedia. (2018). Foreign Direct Investment - FDI. Retrieved July 25, 2018, from

https://www.investopedia.com/terms/f/fdi.asp

Knickerbocker, F. T. (1973). Oligopolistic reaction and multinational enterprise. Boston: Harvard University School of Business Administration.

Krugman, P. (1991). Increasing Returns and Economic Geography. Journal of Political Economy, 99(3).

Kumar, K. (1981). Introduction. (K. Kumar, \& M. G. Mcleod, Eds.) Multinationals from Developing countries.

Lall, S. (1976). Financial and profit performance of MNCs in developing countries: Some evidence from an Indian and Columbian sample. World Development, Elsevier, 4(9 September), 713-724.

letto-Gilles, G. (1992). International Production. Cambridge: Polity Press.

Mariotti, S., \& Piscitello, L. (1995). Information costs and location of FDIs within the host country: Empirical evidence from Italy. Journal of International Business Studies, 26, 815-841.

Marshall, A. (1898). Principles of Economics (Vol. 1). London: Macmillan.

Mittelstaedt, R. (1977). Teaching Consumer Behavior: an Overview. (D. P. William, Ed.) Advances in Consumer Research, 4, pp. 266-267.

Nayyar, R. (2014). Traditional and Modern Theories of FDI. International Journal of Business and Management Invention, 3(6), 23-26.

Ndiaye, G., \& Xu, H. (2016). Impact of Foreign Direct Investment (FDI) on Economic Growth in WAEMU from 1990 to 2012. International Journal of Financial Research, 7 (4), 33-43.

Robock, S. H., \& Simmonds, K. (1983). International Business and Multinational Enterprises. Illinois, United States.: Richard D. Irwin.

Stewart, T. (1994). Trade Related Investement Measures (Vol. GATT Uruguay Round: A Negotiating History). Boston: Kluver.

Vernon, R. (1966). International investment and international trade in the product cycle. Quarterly Journal of Economics, 80(2).

Wacker, J. G. (1998). A definition of theory: research guidelines for different theory-building research methods in operations management. Journal of Operations Management, 361-385.

Wells, L. T. (1968). A product life cycle for international trade? Journal of Marketing, 33(July), 1-6.

Zaltman , G., \& Wallendorf, M. (1979). Consumer Behaviour. New York: John Wiley and Sons. 